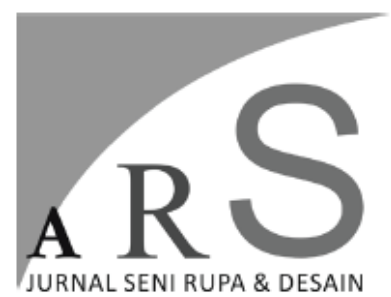

Volume 21 Nomor 1 April 2018

\section{DESKRIPSI PEMASARAN PAMERAN \\ ABSTRACT PARTY BOROBUDUR TODAY 2018 DI GALERI LIMANJAWI ART ART HOUSE}

\author{
Alfiyati Baroroh \\ Program Studi Tata Kelola Seni, Jurusan Tata Kelola Seni \\ Fakultas Seni Rupa, Institut Seni Indonesia Yogyakarta
}

\begin{abstract}
ABSTRAK
Penelitian ini akan difokuskan pada penerapan teori bauran pemasaran 4P (Produk, Harga, Tempat, Promosi) dan STP (Segmentasi, Target Sasaran, Pemosisian) yang merupakan pengembangan dari konsep strategi pemasaran. Metode penelitian yang digunakan adalah metode kualitatif dengan pendekatan deskriptif. Pengumpulan data dilakukan melalui observasi, dokumentasi dan wawancara. Melalui metode tersebut dapat diketahui sejauh mana Limanjawi menerapkan teori pemasaran bauran pemasaran 4P dan STP. Hasil dari penelitian ini yaitu produk yang di pasarkan berupa pameran dan pertunjukan seni dengan sistem free entry dan dilaksanakan di daerah wisata sehingga memudahkan pemasaran, selain itu promosi dilakukan melalui berbagai media baik advertising, public relation, dan personal selling. Kedua yaitu perumusan strategi STP yang diterapkan dalam pameran Abstract Party. Segmen pengunjung yaitu demografis, geografis, dan psikografis, serta target sasaran merupakan segmen georgrafis dan psikografis. Limanjawi sebagai galeri memposisikan diri sebagai galeri yang unik dan berbeda dari galeri lain di Borobudur.
\end{abstract}

Kata kunci: pameran, strategi pemasaran, bauran pemasaran 4P, dan STP.

\section{ABSTRACT}

This research will focus on the application of $4 P$ marketing mix theory (Product, Price, Place, Promotion) and STP (Segmentation, Targeting, Positioning) which is the development of the marketing strategy concept. The research method used is qualitative method with descriptive approach. The collection of data obtained through observation, documentation and interview. through the method can be known to what extent Limanjawi apply marketing theories of $4 P$ marketing mix and STP. The results of this research are products that are marketed in the form of exhibitions and art shows with free entry system. The Exhibition held in the tourist area makes it easy for marketing. In addition, the promotion is done through various media such as advertising, public relations, and personal selling. then the formulation of STP strategy applied in the Abstract Party exhibition. Visitor segments ie demographic, geographic and psychographic, and the target is georgrafis and psychographic segments. Limanjawi gallery position as unique and different galleries from other galleries in Borobudur.

Keywords: exhibition, marketing strategy, 4P marketing mix, and STP. 


\section{Pendahuluan}

Magelang merupakan salah satu daerah yang terletak di provinsi Jawa Tengah. Kota ini memiliki cagar budaya yang diakui sebagai warisan dunia, yaitu Candi Borobudur yang dibangun pada abad VII-IX M. (Dian, 2016, hal. 13). Candi peninggalan Dinasti Syailendra ini bahkan telah diakui menjadi Warisan Dunia oleh UNESCO. Candi Borobudur terdaftar sebagai warisan Dunia sejak tanggal 13 Desember tahun 1991 dengan nomor 348 dan diperbarui menjadi Nomor C 592 tahun 1991. (Borobudur B. K., 2016, hal. 3) Candi Borobudur memiliki banyak sekali keragaman budaya dan kesenian. Jumlah kunjungan wisatawan dari tahun ke tahun cenderung meningkat, data terakhir tahun 2014 jumlah pengunjung candi borobudur mencapai 3 juta orang dalam satu tahun. (Wahyuningsih, Vol 10 No. 2 Desember 2016, hal. 49)

Jumlah wisatawan di Borobudur membuat peningkatan ekonomi masyarakat Borobudur sendiri. Masyarakat setempat mulai membuka peluang usaha untuk meningkatkan ekonomi mereka, hal ini dibuktikan dengan banyaknya penginapan dan restoran yang dibuka di daerah Borobudur. Kecamatan Borobudur sendiri terdapat 21 hotel dari kelas melati hingga bintang 5, 130 homestay, serta 15 restoran. (Borobudur K. K., 2018) Banyaknya hotel, restoran, dan homestay, di daerah Borobudur memunculkan industri di sekitar Borobudur. Masyarakat banyak yang membuka tempat wisata untuk disuguhkan kepada wisatawan, setidaknya di area Borobudur terdapat 88 objek wisata yang berbagai jenis serta menjadi daya tarik untuk wisatawan, salah satunya yaitu galeri.

Galeri "Limanjawi Art House" adalah galeri yang terletak di Borobudur terletak di timur Candi Borobudur di Dusun Tingal Wetan, Desa Wanurejo. Limanjawi secara resmi berdiri sebagai galeri seni pada tahun 2009, hal ini digagas oleh Umar Chusaeni bersama KSBI 15 (Komunitas Seniman Borobudur Indonesia Lima Belas). Sejak saat itulah kegiatan- kegiatan seni dan budaya seperti pameran seni rupa, festival, dan pertunjukan seni tradisional digelar di Limanjawi Art House. Visi dan misi Limanjawi Art House bukan hanya untuk mengembangkan dan melestarikan seni rupa Indonesia, tujuan dari galeri ini juga menjadi sebuah lembaga seni yang mengedukasi masyarakat di daerah magelang khususnya Borobudur untuk dapat belajar mengenai ilmu seni rupa. (Chusaeni, Wawancara, 2018). Galeri Limanjawi memiliki konsep bangunan tradisional atau etnik, hal ini karena galeri ini juga menawarkan produk barang antik untuk dijual kepada wisatawan atau pengunjung yang datang. Puluhan pameran sudah pernah diselenggarakan di Limanjawi, salah satu pameran yang rutin digelar di Limanjawi Art House yaitu pameran Borobudur Today.

Pameran Borobudur Today adalah merupakan salah satu pameran rutin yang diadakan oleh Limanjawi Art House, pameran ini diselenggarakan satu tahun sekali. Pameran Borobudur Today pertama diselenggarakan pada tahun 2014, yang kedua pada tahun 2015-2016, yang ketiga digelar pada 18 Maret 2017. Pameran Borobudur Today menjadi agenda tahunan di kawasan Borobudur khususnya di galeri Limajawi Art House. Pameran Borobudur Today biasanya melibatkan puluhan hingga ratusan seniman dari berbagai daerah di Indonesia dan mancanegara. (Rosidi, 2017) Pada tahun 2018 ini Limanjawi Art House menggelar pameran Borobudur Today yang berjudul Abstract Party Borobudur Today 2018, yang digelar pada tanggal 11 Maret sampai dengan 11 April 2018. Pameran Abstract Party ini mampu mendatangkan 383 pengunjung dalam pembukaan pameran (Buku Tamu Pameran Abstract Party Borobudur Today 2018 ) hal ini yang memicu penelitian pemasaran pameran yang diselenggarakan oleh galeri Limanjawi Art House beserta tim menarik untuk diteliti.

1. Pameran

Pameran adalah sebentuk alat sajian pertanggung jawaban bagi perupa (maupun kurator) sesuai melakukan atau menunjukan karya seninya kepada khalayak. (Susanto, Menimbang Ruang 
Menata Rupa, 2004) Sedang bagi non perupa pameran juga dianggap sebagai cara untuk menggali berbagai kemampuan dan kebutuhan yang ingin disampaikan pada orang lain. Bagi para pengelola pameran dan seniman harus mengetahui bagaimana cara menyajikan pameran dengan kreatif agar dapat menarik perhatian penonton. Penyelenggara dan pengelola baik seperti di galeri, museum, manajer, dan lainnya, pameran dapat dianggap sebagai ajang memperoleh nilai baik itu profit maupun non profit. Pada dasarnya seni memang memiliki tujuan seperti politik, sosial, ekonomi, moral atau untuk kesenian itu sendiri. Pameran dapat digolongkan berdasarkan jenis, karakter, tempo, publik dan pasar.

2. Strategi Pemasaran

Strategi pemasaran adalah pendekatan pokok yang akan digunakan oleh unit bisnis dalam mencapai sasaran yang telah ditetapkan lebih dulu, di dalamnya tercantum keputusan-keputusan pokok mengenai target pasar, penempatan produk dipasar, bauran pemasaran, dan tingkat biaya pemasaran yang diperlukan. (Sunyoto, 2015, hal. 2) Strategi pemasaran pada dasarnya adalah sebuah rencana yang menyeluruh, terpadu, dan menyatu dibidang pemasaran, yang memberikan acuan tentang kegiatan yang akan dijalankan untuk dapat tercapainya tujuan pemasaran suatu perusahaan.

3. Bauran Pemasaran 4P (Produk, Harga, Tempat, Promosi)

Pemasar atau sebuah perusahaan harus memutuskan berapa banyak untuk menyesuaikan strategi pemasaran mereka. Dipandu dengan stategi pemasaran, perusahaan atau pemasar akan menentukan sebuah bauran pemasaran terintegrasi. Bauran pemasaran tersebut tediri dari faktor- faktor dibawah kendalinya, yaitu produk, harga, tempat dan promosi. (Kotler P. , 2000, hal. 379)

a. Produk

Produk merupakan objek intangible ataupun tangible yang diciptakan oleh perusahaan yang disebut produsen, kemudian ditawarkan dan pasarkan kepada pasar atau konsumen, jenis produk bisa berupa barang maupun jasa. Produk merupakan sesuatu yang dapat memuaskan kebutuhan konsumen. Untuk mengembangkan suatu produk untuk ditawarkan kepada pasar, perencanaan produk dibedakan menjadi tiga tingkatan konsep produk, yaitu produk inti, produk nyata, dan produk tambahan.

b. Harga

Harga merupakan sebuah nilai atau sejumlah uang yang harus dibayarkan konsumen untuk memperoleh sebuah produk. Harga dikendalikan oleh produsen, namun harus berorientasi pada pasar. Supaya terjadi transaksi, harga harus sesuai antara konsumen dan penyedia produk (Philip Kotler, 2009) Salah satu yang mempengaruhi penetapan harga adalah reaksi pesaing, yaitu dari penetapan harga yang berasal dari produk yang serupa, produk pengganti dan produk yang tidak serupa. (Sunyoto, hal. 16) Salah satu metode strategi penetapan harga yaitu melalui Going gate pricing yang berarti perusahaan berusaha menetapkan harga setingkat dengan rata-rata industri atau pesaing yang lain. Metode ini digunakan jika biayanya sulit diukur dan harga yang berlaku di pasar dapat memberikan keuntungan yang layak.

c. Tempat

Tempat termasuk aktifitas perusahaan yang membuat produk tersedia untuk konsumen yang ditargetkan. Tempat yang dimaksud berhubungan dengan distribusi, tempat dimana calon konsumen bisa mendapatkan produk tersebut (Kotler P. d., 2009, hal. 119)

d. Promosi

Promosi adalah cara memperkenalkan suatu produk kepada konsumen, atau aktifitas perusahaan dan pemasar yang 
mengkomunikasikan manfaat produk atau membujuk konsumen yang ditargetkan untuk menggunakan produk tersebut. Tujuan dari promosi adalah menimbulkan kesadaran atau pengetahuan sehingga konsumen membeli produk tersebut. Promosi adalah hal yang paling tampak dari proses pemasaran. Promosi juga mencangkup semua bentuk komunikasi dengan konsumen dari iklan massal hingga pengembangan presentasi penjualan personal. (Kotler P. d., 2009, hal. 119)

4. Beberapa macam jenis promosi

a. Advertising

Merupakan pendekatan promosi dengan cara mengiklankan produk pada media periklanan seperti media cetak, media elektronik, dan media sosial. Dan mediamedia tersebut seperti koran, televisi, website, dan beberapa akun media sosial.

b. Public Relation

Public Relation adalah suatu usaha yang direncanakan secara terus-menerus dengan sengaja, hal ini untuk membangun dan mempertahankan hubungan antara pemasar atau perusahaan dengan masyarakat atau lingkungannya. Pemasar atau perusahaan menggunakan strategi public relation untuk tujuan jangka panjang membangun citra positif perusahaan atau pemasar.

c. Personal Selling

Personal Selling merupakan interaksi antar individu yang saling bertemu muka, yang ditujukan untuk menciptakan, memperbaiki, menguasai dan mempertahankan hubungan pertukaran yang saling menguntungkan kedua pihak. Dalam personal selling, terjadi komunikasi secara langsung antara pemasar dengan calon pembeli, pemasar mengkomunikasikan produk kepada calon pembeli. Segmentasi, Target Sasaran, dan Pemosisian (STP)

5. Segmentasi, Target Sasaran, dan
Pemosisian atau yang disebut STP

Merupakan salah satu perumusan strategi pemasaran, atau menggabungkan proses penciptaan dan penyampaian nilai kepada konsumen ke dalam bentuk disebut juga dengan istilah STP. Strategi pemasaran STP adalah proses mengkategorikan pasar, kemudian membidik pasar yang diinginkan, lalu memposisikan pemasaran perusahaan atau pemasar dibandingkan dengan pesaing. Strategi ini dapat membantu pemasar atau perusahaan untuk menentukan strategi yang dapat dilakukan untuk memasarkan produknya. Dengan STP pemasar dapat menjual produknya dengan tepat.

6. Segmentasi

Segmentasi pasar pada dasarnya adalah suatu strategi untuk memahami struktur pasar. Definisi segmentasi pasar yang paling sering diucapkan para ahli adalah "suatu proses untuk membagi- bagi atau mengelompokan konsumen kedalam kotakkotak yang lebih homogen". Jadi segmentasi pasar adalah merupakan suatu usaha untuk mengelompokan pasar dari pasar yang bersifat heterogen menjadi bagian-bagian pasar yang memiliki sifat homogen. (Sunyoto, 2015, hal. 93) Parameter yang digunakan untuk mengidentifikasi serta kemudian menentukan segmentasi, yaitu:

a. Demografis (umur Jenis kelamin, tingkat pendidikan, penghasilan, agama, status perkawinan, suku dan lain- lain)

b. Geografis (negara, wilayah atau kota tertentu)

c. Psikografis (kelas sosial, kepribadian, dan gaya hidup)

Pemasar kemudian dapat memutuskan segmen mana yang memberikan peluang terbesar untuk mereka yang kebutuhannya dapat dipenuhi oleh pemasar dengan cara yang lebih baik. Segmentasi pasar yang digunakan dalam penelitian ini untuk mengulas pemasaran pameran merupakan segmentasi apriori. Segmentasi apriori yaitu segmentasi yang dilakukan sebelum produk, jasa, atau ide diluncurkan kepada pasar. 


\section{Target Sasaran}

Target Sasaran dalah langkah selanjutnya setelah segmentasi, langkah ini membahas persoalan tentang bagaimana cara memilih, menyeleksi dan menjangkau pasar. Hal ini dilakukan karena pasar yang dilihat oleh dua orang yang berbeda, yang didekati dengan segmentasi yang berbeda maka akan menghasilkan peta yang berbeda juga. Produk dari target sasaran sendiri adalah target market (pasar sasaran), yaitu satu atau beberapa segmen pasar yang akan menjadi fokus kegiatan-kegiatan pemasaran. Pemasar harus memfokuskan kegiatannya pada suatu atau beberapa bagian saja (segmen) dan meninggalkan bagian lainnya.

\section{Pemposisian}

Pemposisian merupakan proses selanjutnya setelah target sasaran sudah dipilih. Pemosisian pada dasarnya merupakan suatu strategi untuk memasuki otak konsumen. Pemosisian bukan sesuatu yang anda lakukan terhadap produk, tetapi sesuatu yang anda lakukan terhadap otak calon pelanggan. Dilengkapi juga dengan pernyataan yang menyatakan bahwa pemosisian juga merupakan suatu usaha untuk membangun presepsi untuk produk pemasar didalam pasar sasaran relatif terhadap persaingan. Untuk membedakan produk kita dengan produk pesaing lain maka dilakukan diferensiasi produk, yaitu merupakan suatu usaha atau strategi untuk menciptakan sesuatu yang dipandang unik di pasar.

\section{Metode Penelitian}

Metode yang digunakan dalam penelitian ini adalah kualitatif dengan pendekatan deskriptif. (Suryabrata, 2012, hal. 75) Yaitu suatu metode dalam meneliti status kelompok manusia, suatu objek, suatu set kondisi, suatu sistem pemikiran, ataupun suatu kelas peristiwa pada masa sekarang. Tujuan dari penelitian deskriptif ini adalah untuk membuat deskripsi, gambaran atau lukisan secara sistematis, faktual dan akurat mengenai fakta-fakta, sifat-sifat serta hubungan antar fenomena yang diselidiki.

\section{Populasi dan Sampel}

Populasi merupakan jumlah keseleluruhan dari seluruh analisis yang general serta lebih luas. Populasi dalam penelitian ini adalah Galeri Limanjawi Art House. Sampling atau sampel berarti contoh, yaitu sebagian dari seluruh individu yang menjadi objek penelitian (Mardalis, 2004) Bagian ini yang akan dibahas dalam penelitian secara spesifik dan detail serta akan menjadi pusat perhatian yang akan di selidiki. Sampel dalam penelitian ini adalah strategi pemasaran pameran Abstract Party Borobudur Today 2018, yang berlangsung di galeri Limanjawi Art House.

\section{Metode Pengumpulan Data}

Metode pengumpulan data yang digunakan dalam penelitian ini menggunakan teknik pengumpulan data melalui observasi, wawancara, dokumentasi dan studi pustaka. Observasi yang dilakukan oleh penulis adalah dengan teknik terjun langsung ke lapangan dengan mengunjungi pameran di galeri Limanjawi Art House. Penelitian tersebut berlangsung dalam kurun waktu 2 bulan. Observasi yang dilakukan yaitu berupa observasi nonpartisipan, dalam pengamatan ini peneliti tidak terlibatan ke dalam event. Wawancara adalah proses memperoleh keterangan untuk tujuan penelitian dengan cara tanya jawab, sambil bertatap muka antara pewawancara dengan responden dengan menggunakan alat yang dinamakan panduan wawancara (Nazir M. , 2014) Wawancara dilakukan terhadap pemilik Galeri Limanjawi Art House yaitu Umar Chusaeni, penulis pameran Abstract Party Borobudur Today 2018 Anton Larenz, pegiat dan kolektor seni yaitu Oei Hong Djien atau lebih dikenal dengan nama museumnya OHD.

Dokumentasi dalam penelitian ini adalah untuk mendapatkan informasi yang berhubungan dengan data- data tentang berbagai hal yang berhubungan dengan 
pemasaran pameran Abstract Party Borobudur Today 2018 di Galeri Limanjawi Art House Studi Pustaka Penelitian ini dilakukan dengan mengumpulkan informasi dan data dengan bantuan berbagai macam material studi pustaka seperti literatur buku, dokumen, jurnal dan tentunya referensi yang relevan serta terpercaya sebagai sumber data penelitian ini.

\section{Pembahasan}

\section{Limanjawi Art House}

Limanjawi Art House merupakan suatu lembaga seni yang berada di sebelah timur Candi Borobudur. Limanjawi terletak di Dusun Tinggal Kulon, Desa Wanurejo, Kecamatan Borobudur, dan Kabupaten Magelang. Desa Wanurejo merupakan salah satu desa wisata di area komplek candi Borobudur. Candi Borobudur seRdimie merupakan salah satu sumber daya budaya di Indonesia dan terdaftar dalam World Heritage No. C 592 tahun 1991. Selain tradisi, kesenian dan kerajinan, di desa ini terdapat, beberapa galeri seni. Salah satunya adalah galeri seni Limanjawi Art House.

Limanjawi berdiri pada tahun 2002, tetapi secara resmi mulai aktif sebagai lembaga seni ataupun galeri pada tahun 2009. Galeri Limanjawi didirikan oleh seniman asal Temanggung yang tinggal di Borobudur, yaitu Umar Chusaeni bersama istri yang juga seorang seniman asal Jepang yaitu Yasumi Ishii. Limanjawi masuk ke dalam salah satu daftar daya tarik wisata di Borobudur dari 88 daftar daya tarik wisata di Borobudur. Limanjawi bukan satu-satunya galeri seni rupa di daerah Borobudur. Setidaknya terdapat 8 galeri dan 2 museum yang terletak disekitar Borobudur. (Borobudur K. , 2018) Galeri dan museum yang terletak di Borobudur tersebut tidak semua menggelar kegiatan pameran, sebagian mereka hanya mengkoleksi barang antik dan lukisan untuk diperjual belikan secara langsung digaleri tanpa harus menggelar kegiatan pameran. (Chusaeni, Galeri Limanjawi Art House, 2018)

Berikut beberapa galeri dan museum yang juga menggelar kegiatan pameran seperti
Padepokan Apel Watoe, Banyu Bening Art House, Galeri Bumayasta, Elo Progo Art House dan Museum H. Widayat. Galeri Limanjawi menjadi satu-satunya galeri yang cukup aktif mengadakan pameran di Borobudur. Jumlah pameran yang digelar di Limanjawi satu tahun bisa mencapai 6 kali, hal ini lebih banyak jika dibandingkan jumlah pameran di Padepokan Apel Watoe yang hanya sekitar 3 sampai 4 kali dalam satu tahun. (Paw, 2018) Dalam pengemasan pameran mereka hampir sama dengan Limanjawi yaitu menyuguhkan karya seniman lokal atau internasional, namun mereka jarang menyuguhkan kesenian tradisional dalam pembukaan pameran. Salah satu pameran yang diadakan di Limanjawi yaitu pameran Abstract Party Borobudur Today 2018.

\section{Pameran Abstract Party Borobudur Today 2018}

Borobudur Today merupakan sebuah kegiatan pameran yang dilaksanakan di galeri Limanjawi serta digelar secara regular dan berkala. Pameran ini merupakan pameran annual atau digelar setiap tahunnya. (Susanto, 2004) Pameran ini merupakan sebuah pameran yang digagas langsung oleh Umar Chusaeni bersama KSBI 15 (Komunitas Seniman Borobudur Lima Belas). Pameran Borobudur Today dihadirkan dengan tujuan sebagai penanda perkembangan seni rupa di Borobudur terkini (saat pameran dilaksanakan). Kegiatan pameran ini bukan hanya menghadirkan seniman dari Borobudur saja, melainkan dari Jepara, Yogyakarta, Bali, Padang, Solo, Klaten, Jakarta dan seniman dari kota- kota lain di Indonesia bahkan hingga seniman mancanegara seperti China, Jepang dan Vietnam.

Penyelenggara pameran menujukan pameran ini untuk semua kalangan baik itu pegiat seni maupun tidak, ia mengharapkan pameran ini dapat diakses dan dinikmati oleh segala usia dan profesi namun lebih dikhususkan untuk pegiat seni. Pada tahun 2018 Limanjawi menggelar pameran Borobudur Today dengan judul dan tema 
"Abstract Party". Abstract Party merupakan konsep, tema dan judul yang digunakan dalam pameran annual Borobudur Today 2018. Pameran ini digelar pada tanggal 11 Maret sampai 11 April 2018, dan dibuka oleh Oei Hong Djien pada Minggu, 11 Maret pukul 09.00 WIB. Abstract Party merupakan sebuah pameran bersama yang menghadirkan 24 seniman. Pameran ini dibuka untuk umum dan 24 jam, selain itu tidak ada pemungutan biaya untuk tiket masuk. Kata Abstract Party dalam bahasa Indonesia berarti "pesta abstrak", dapat disimpulkan bahwa dalam pameran kali ini mengusung tema abstrak.

Pameran ini menangkap apa yg terjadi dalam dua tahun terakhir di galeri Limanjawi. Dua tahun terakhir ini pengelola galeri sekaligus pemilik mengamati bahwa banyak tamu atau pengunjung di Limanjawi yang tertarik dengan karya abstrak. Abstrak merupakan salah satu aliran yang tidak dapat dijelaskan wujudnya dan dianggap tidak berbentuk. Untuk itu beberapa waktu yang lalu abstrak dirasa kurang diminati, sehingga harga karya abstrak dibandingkan dengan lukisan figuratif dengan nama seniman yang setara dinilai jauh di bawah. Berdasarkan hasil observasi Oei Hong Djien menyatakan bahwa lukisan abstrak dan figuratif di luar negeri nilainya sama, bahkan abstrak sudah banyak diperhatikan.

Fenomena tersebut yang akhirnya membawa pengaruh perkembangan abstrak sampai di Indonesia. Konsep dan tema Pameran Abstract Party berasal dari kosmologi candi Borobudur, yaitu salah satu tingkat susunan candi Borobudur yang bernama Arupadhatu. (House, 2018) Arupadhatu adalah tingkat tertinggi dari Candi Borobudur dan simbol untuk sifat atau karakter esensial yang telah dibebaskan dari keinginan, semua masalah duniawi dan tidak terikat lagi pada karma, terlepas dari bentuknya (tidak berwujud) atau tidak berbentuk. Arupadhatu juga disebut sifat para dewa dan simbol kesucian Buddha di mana kebahagiaan dan kebijaksanaan sejati terletak.

Jumlah pengunjung dalam pembukaan pameran Abstracy Party mencapai 383 pengunjung. (Pameran, 2018) Pengunjung yang datang dalam pameran ini terdiri dari beberapa kalangan, sebagian adalah merupakan pegiat dan pelaku seni, sebagian adalah wisatawan di Borobudur, serta sebagian lagi adalah masyarakat setempat. Pameran Abstract Party menghadirkan 24 seniman untuk berpartisipasi memamerkan karyanya dalam pameran ini. sebanyak 21 seniman berasal dari kota-kota di Indonesia, sedangkan 3 seniman lainnya berasal dari manca negara. Pameran ini menampilkan karya sebanyak 29 karya, diantaranya yaitu 4 karya jenis patung, 1 karya digital printing, dan 24 karya lukisan. Karya seni yang dipamerkan dalam pameran Abstract Party ini adalah jenis karya abstrak. Pemilihan karya dipilih langsung oleh Umar Chusaeni selaku pemilik galeri Limanjawi sekaligus penyelenggara pameran dan dibantu oleh KSBI 15. Pameran Abstract Party disajikan dengan kreatif serta menampilkan inovasi baru. Seluruh kreativitas penyajian pameran Abstract Party Borobudur Today 2018 bertujuan untuk membuat para pengunjung tertarik datang dan mengapresiasi pameran ini, serta nyaman berada di Limanjawi.

\section{Dekorasi Panggung}

Dalam penyajian dekorasi panggung Limanjawi dan tim KSBI 15 menyajikan dekorasi yang berbeda. Dekorasi panggung disesuaikan dengan konsep pameran yaitu abstrak. Bahan yang digunakan seperti karung beras yang digambar abstrak oleh KSBI 15, daun-daunan, dan jerami serta alat- alat gamelan. Dekorasi luar ini penting karena hal ini visual yang pertama kali dilihat oleh para pengunjung ataupun wisatawan. Berikut gambar dekorasi panggung pembukaan pameran Abstract Party: 


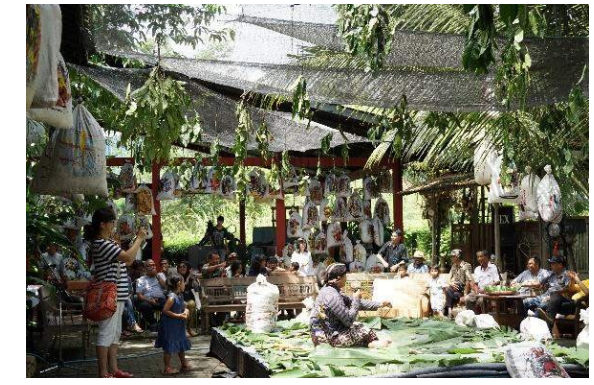

Gambar 1. Dekorasi Panggung Pembukaan.

(Sumber: Alfiyati Baroroh. 2018)

\section{Pertunjukan Kesenian}

Pameran ini juga menampilkan berbagai kesenian tradisional berupa tari-tarian, serta pertunjukan seni seperti monolog tari, dan musik sebagai hiburan saat pembukaan. Limanjawi dalam pameran Abstract Party ini menyuguhkan beberapa kesenian tradisional yang berasal dari Indonesia khususnya Borobudur dalam pembukaan pameran. Kombinasi pameran seni rupa dengan seni pertunjukan menjadikan galeri Limanjawi berbeda dengan galeri lain yang ada di Borobudur. Hal ini merupakan upaya diferensiasi atau melakukan suatu usaha agar produk pameran ini berbeda dengan galeri lain yang ada di Borobudur. Pertunjukan ini menjadi salah satu strategi pemasaran pameran dalam Limanjawi. Berikut ini suasana pembukaan pameran Abstract Party di Limanjawi Art House.

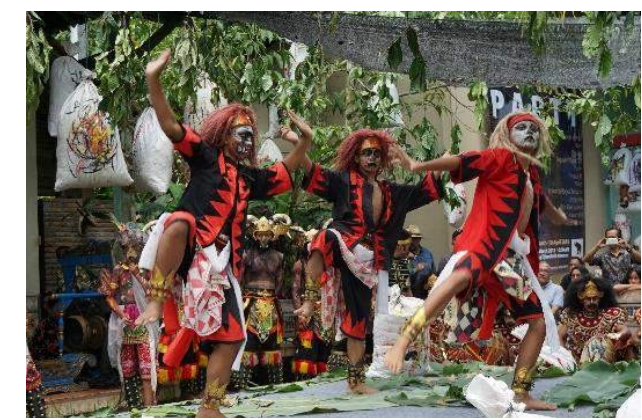

Gambar 2. Penampilan Kesenian Jingkrak Sundang.

(Sumber: Alfiyati Baroroh. 2018)

\section{Bauran Pemasaran (4P)}

Bauran pemasaran dari produk, harga, promosi, dan distribusi adalah istilah di mana perusahaan mewujudkan strateginya dari sebuah pernyataan tujuan untuk berusaha dipasar. Berikut adalah hasil analisis dari data wawancara dan observasi mengenai fokus dan strategi Limanjawi dalam memasarkan pameran Abstract Party Borobudur Today 2018, melalui bauran pemasaran, yaitu:

\section{Produk}

\section{Produk Inti}

Produk inti merupakan produk yang menjadi jawaban dari kebutuhan apa yang sedang dicari konsumen, serta kebutuhan apa yang dipuaskan dari produk tersebut. Produk inti yang dimaksud di sini adalah Pameran Abstract Party Borobudur Today 2018. Pameran ini diselenggarakan oleh galeri Limanjawi Art House dan KSBI 15. Produk lain dari kegiatan ini yaitu pertunjukan kesenian tradisional, monolog tari, dan seni musik yang ditampilkan dalam acara pembukaan pameran. Perencanaan pameran ini didasari dari pengamatan langsung pemilik Limanjawi dan penyelenggara pameran, bahwa pengunjung galeri lebih tertarik dengan karya abstrak dua tahun terakhir ini. Pameran ini dapat dinilai sukses pengunjung dalam pembukaan pameran berdasarkan buku tamu mencapai 383 pengunjung. (Buku Tamu Pameran Abstract Party Borobudur Today 2018, Borobudur, 11 Maret 2018.)

\section{Produk Nyata}

Produk nyata adalah produk yang dibuat agar dapat dilihat atau dirasakan secara langsung untuk ditawarkan kepada konsumen. (Sunyoto, Strategi Pemasaran, 2015)(Danang Sunyoto, Strategi Pemasaran (Yogyakarta: CAPS (Center for Academic Publishing Service), 2015), hal. 31.) Produk nyata dalam pameran abstract party ini adalah karya-karya yang ditampilkan pada pameran Abstract Party. Produk yang dipasarkan memiliki bentuk yang berupa lukisan, patung dan digital printing. Seluruh karya yang ditampilkan beraliran abstrak yang sesuai dengan tema pameran ini. Kualitas karya yang ditampilkan sangat baik, hal ini karena karya dihasilkan oleh senimanseniman yang profesional. Jumlah karya yang disajikan dalam pameran Abstract Party ini ada 
29 karya, yaitu 4 karya patung, 1 karya digital printing, dan 24 sisanya adalah lukisan.

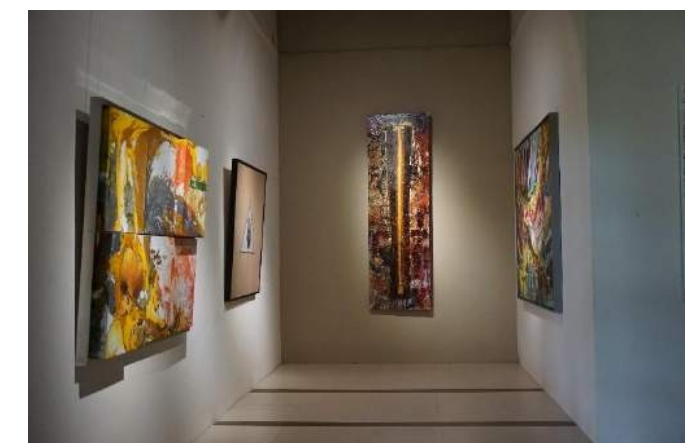

Gambar 3. Karya Di Pameran Abstract Party Borobudur Today 2018.

(Sumber: Alfiyati Baroroh, 2018)

\section{Produk Tambahan}

Produk tambahan merupakan produk yang menyertai produk nyata untuk menambah keuntungan kepada konsumen. Produk- produk tambahan dalam pameran Abstract Party ini merupakan kegiatan-kegiatan yang mendukung pameran ini. Seperti menyajikan produk kuliner tradisional pengunjung pameran ketika pembukaan, serta dekorasi panggung pembukaan di luar ruang galeri yang dikemas seartistik mungkin. Bukan hanya menampilkan karya-karya seni rupa namun Limanjawi juga menampilkan berbagai macam kegiatan untuk memenuhi kebutuhan tambahan pengunjung pameran. Hal ini menjadikan pameran Abstact Party ini berbeda dengan pameran digaleri lain. Selain itu kegiatan ini juga menarik perhatian para pengunjung untuk datang mengapresiasi pameran Abstract Party.

\section{Harga}

Harga merupakan sebuah nilai atau sejumlah uang yang harus dibayarkan konsumen untuk memperoleh sebuah produk. (Kotler P. , Marketing Management, 2000) untuk melihat pameran Asbtract Party gratis, Limanjawi tidak memungut biaya sama sekali untuk tiket masuk. Pengunjung baik dari lokal maupun internasional bebas melihat pameran Abstract Party. Hal ini disesuaikan dengan sistem pameran galeri lain di Borobudur yang biasanya juga tidak memungut biaya tiket masuk. Harga tersebut sesuai dengan metode penetapan Going gate pricing yang berarti perusahaan berusaha menetapkan harga setingkat dengan rata-rata industri atau pesaing yang lain. Karya seniman yang ditampilkan menjadi produk untuk dipasarkan. Harga untuk karya ditentukan oleh kesepakatan Limanjawi Art House dan seniman yang bersangkutan. Hal ini sesuai dengan strategi penentuan harga dimana harga dikendalikan oleh produsen, namun harus berorientasi pada pasar. Supaya terjadi transaksi, harga harus sesuai antara konsumen dan penyedia produk. Distribusi untuk pengiriman karya tergantung pada kesepakatan antara konsumen dan Limanjawi. Apabila kolektor atau konsumen menyerahkan pada Limanjawi maka biaya pengiriman ditanggung Limanjawi. Jika pengiriman karya ditanggung oleh kolektor maka biaya pengiriman ditanggung oleh kolektor atau konsumen, biasanya pengiriman karya ini jika dalam volume besar atau keluar negeri. Karya yang dibeli juga dapat langsung dipacking dan dibawa langsung oleh konsumen atau kolektor, hal ini bisa meminimalisir biaya pengiriman.

\section{Tempat}

Lokasi pameran Abstract Party diselenggarakan di galeri Limanjawi Art House yang bertempat di kawasan wisata Candi Borobudur. Limanjawi sangat diuntungkan dengan lokasi yang hanya berjarak 500 meter dari kawasan wisata Candi Borobudur, hal ini karena candi Borobudur merupakan sebuah warisan budaya dunia diakui UNESCO. Rata-rata pengunjung kurang lebih 5.000 per hari, dan jumlah pengunjung yang per tahun mencapai 3 juta pengunjung pada tahun 2014 dan selalu bertambah setiap tahunnya. (Wahyuningsih, Meninjau Kembali Tujuan Pendirian dan Fungsi Museum di Kompleks Taman Wisata Candi Borobudur., 2016) (Apabila ada $10 \%$ saja pengunjung yang tertarik dengan seni budaya otomatis mereka juga akan ada keingintahuan tentang perkembangan seni budaya di Borobudur. Lokasi Limanjawi dinilai cukup terjangkau 
jaraknya dari penginapan dan hotel-hotel diarea Borobudur. Kecamatan Borobudur sendiri terdapat 21 hotel dari kelas melati hingga bintang 5, 130 homestay, serta 15 restoran. Selain itu Limanjawi juga terletak diantara 88 objek wisata yang masuk kedalam data daya tarik untuk wisata di Borobudur. Letak Limanjawi yang berada di kawasan wisata Candi Borobudur membuat wisatawan dan pengunjung yang datang ke Borobudur mudah untuk menemukan lokasi galeri Limanjawi Art House. Selain itu Limanjawi juga terletak di Desa Wisata Wanurejo, desa ini adalah merupakan salah satu destinasi wisata untuk para wisatawan yang berada di Borobudur. Limanjawi juga menjadi daya tarik wisata di Borobudur yang masuk dalam kategori galeri. ${ }^{56}$ Limanjawi Art House terletak di dekat galeri seni rupa yang lain, seperti Padepokan Apel Watoe, Elo Progo Art House, Banyu Bening Art House, galeri Bumayasta. Museum H. Widayat. Galeri lain yang paling dekat yaitu Gallery Bumayasasta galeri ini terletak paling dekat yaitu tepat di depan galeri Limanjawi.

\section{Promosi}

Promosi adalah cara memperkenalkan suatu produk kepada konsumen, atau aktifitas perusahaan dan pemasar yang mengkomunikasikan manfaat produk atau membujuk konsumen yang ditargetkan untuk menggunakan produk tersebut. (Kotler P. , Marketing Management, 2000) Limanjawi dan tim menggunakan beberapa media untuk mempromosikan dan mengenalkan kegiatan pameran Abstract Party Borobudur Today 2018 kepada masyarakat dan wisatawan di daerah Borobudur, Magelang, dan kota lainnya. Beberapa media promosi yang digunakan oleh Limanjawi untuk menginformasikan pameran Abstract Party yaitu:

\section{Advertising}

Merupakan pendekatan promosi dengan cara mengiklankan produk pada media periklanan seperti media cetak, media elektronik, dan media sosial. Dan media- media tersebut seperti koran, televisi, website, dan beberapa akun media sosial. Berikut ini kegiatan promosi yang dilakukan oleh Limanjawi Art House untuk menyebarkan informasi kegiatan pameran Abstract Party Borobudur Today 2018:

Media cetak yang digunakan untuk memberikan informasi tentang kegiatan ini yaitu:

a. Poster

Kegiatan promosi ini dengan menyebar poster disekitar kawasan wisata Candi Borobudur serta tempat-tempat yang strategis di daerah Galeri Limanjawi Art House.

b. Undangan

Limanjawi dan tim melakukan promosi secara manual melalui media cetak dengan menggunakan media undangan. Promosi ini dengan menyebarkan 150 lembar undangan kepada para budayawan, senian, pegiat seni, kolektor seni, lembaga dan instansi pengelola wisata Candi Borobudur, serta rekan pebisnis disekitar Borobudur (pihak penginapan, restauran, dan galeri lain).

c. Katalog Produk

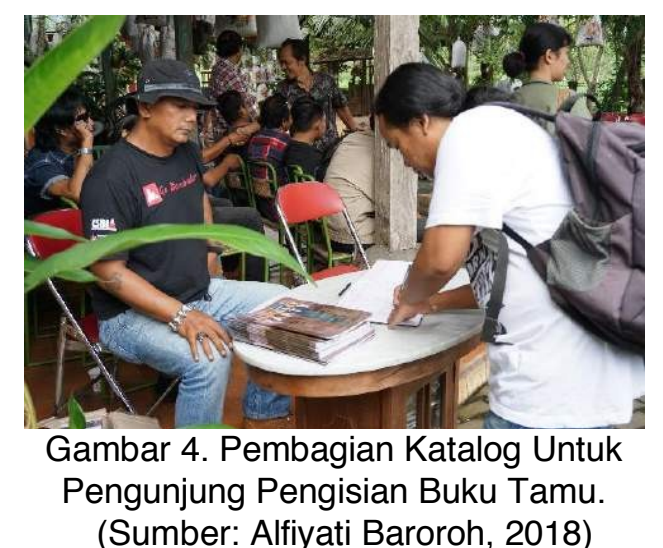

Promosi ini dilakukan dengan membagikan katalog pameran Abstract Party kepada para pengunjung dan wisatawan yang datang berkunjung ke Limanjawi Art House secara gratis. Selain itu ini juga dijadikan strategi pemasaran oleh Limanjawi, apabila kolektor tidak melakukan transaksi di galeri dan berubah 
pikiran sewaktu-waktu mereka dapat melihat karya melalui katalog. Limanjawi menyediakan lebih dari 1000 katalog Abstract Party, menurut Umar Chusaeni lebih baik katalog berlebih daripada kehabisan katalog. Pembagian katalog ini dibagikan kepada seluruh pengunjung tanpa ada pengecualian.

\section{Online Advertising}

Promosi ini dengan menggunakan media online yaitu dengan penggunaan website Limanjawi Art House serta media berita online seperti media Jateng Antara News, Bali Tribun News, I News, Bisnis Jakarta, Borobudur News, Berita Magelang, Siaga Indonesia, Magelang Sorot, Suara Merdeka, dan Bumn.go.id. Berikut salah satu berita media online tentang pameran Abstract Party:

\section{$\equiv \quad<$ NNTARAJATENG \\ 24 perupa pameran "Abstract Party" di Borobudur}

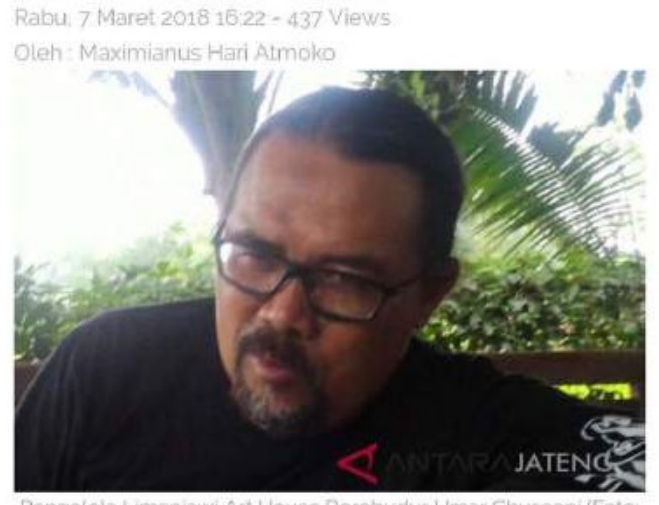

Gambar 5. Berita Online Tentang Pameran Abstract Party.

(Sumber: Berita Online Antara News)

\section{Televisi Advertising}

Pameran Abstract Party diliput oleh salah satu stasiun televisi nasional yaitu RCTI Network Yogyakarta. Liputan tentang pameran Abstract Party ini disiarkan pada Selasa, 13 Maret 2018. (Puji Hartono, Pameran Abstrak Terinspirasi Candi Borobudur Diikuti Puluhan Seniman, https://www.inews.id/daerah/jateng/73242/pa meran-abstrak-terinspirasi-candi borobudur- diikuti- puluhan-seniman (diakses pada $20 \mathrm{Mei}$ 2018, pukul 15.14).

\section{Media Promosi Luar Ruangan Baliho}

Pemasangan Baliho di sepanjang jalan menuju ke lokasi pameran yaitu Limanjawi $A r t$ House, hal ini untuk menginformasikan kegiatan pameran Abstract Party kepada masyarakat setempat serta, wisatawan yang sedang berkunjung ke daerah desa Wanurejo.

\section{Spanduk}

Pemasangan spanduk juga dipasang di sepanjang jalan menuju galeri Limanjawi $A r t$ House, selain untuk menginformasikan kegiatan pameran, hal ini juga menjadi pertanda bahwa tidak jauh dari spanduk di jalan tersebut Limanjawi terletak. Spanduk menggunakan bahasa inggris, hal ini dimaksudkan agar wisatawan dari mancanegara dapat mengerti informasi tersebut.

\section{Media Sosial}
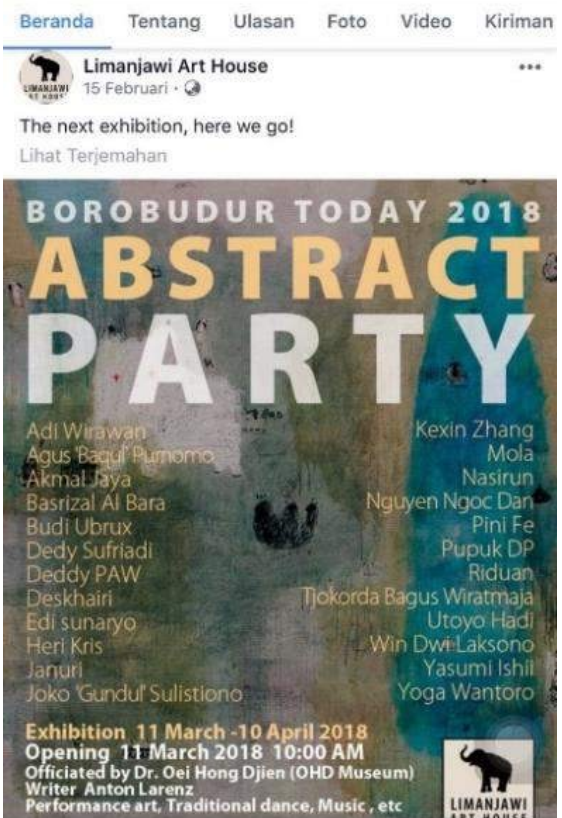

Gambar 6. Halaman Facebook Limanjawi Art House. 2018.

(Sumber: Facebook Limanjawi Art House)

Promosi kegiatan pameran Abstract Party juga menggunakan media sosial, hal ini dengan cara menyebarkan poster melalui beberapa akun media sosial. Media sosial yang digunakan 
bukan hanya media sosial milik Limanjawi pribadi, melainkan bekerja sama dengan pihak lain. Media sosial yang digunakan seperti website dengan alamat website Limanjawi.com, Facebook dan Instagram dengan nama akun yang sama yaitu Limanjawi Art House (Umar Chusaeni, Pemilik Galeri Limanjawi Art House, Wawancara, Borobudur, 9 Maret 2018.) Berikut ini salah satu akun media sosial milik Limanjawi yaitu Facebook:

\section{PublicRelations}

Public Relation adalah suatu usaha yang direncanakan secara terus-menerus dengan sengaja, hal ini untuk membangun dan mempertahankan hubungan antara pemasar atau perusahaan dengan masyarakat atau lingkungannya. Hal ini sesuai dengan promosi public relation yang dilakukan oleh Limanjawi Art House yaitu dengan cara bekerjasama dengan para pelaku wisata di Borobudur. Kerja sama ini dengan para pemandu wisata, travel agent, penginapan dan Himpunan Pramuwisata Indonesia Borobudur (HPI Borobudur) untuk mempromosikan pameran Abstract Party. Promosi dilakukan dengan menyampaikan informasi secara langsung tentang kegiatan pameran di Limanjawi kepada para wisatawan yang menjadi tamu atau konsumen mereka. Limanjawi Art House juga bekerjasama dengan beberapa jurnalis serta wartawan. Jurnalis dan wartawan tersebut akan meliput kegiatan pameran Abstract Party, lalu akan memuat artikel tentang pameran ini dan disebarkan melalui berbagai media seperti media cetak, berita online, dan elektronik.

\section{Personal Selling}

Personal Selling merupakan interaksi antar individu yang saling bertemu muka, yang ditujukan untuk menciptakan, memperbaiki, menguasai dan mempertahankan hubungan pertukaran yang saling menguntungkan kedua pihak. Dalam personal selling, terjadi komunikasi secara langsung antara pemasar dengan calon pembeli, pemasar mengkomunikasikan produk kepada calon pembeli. (Keller, 2009)
Promosi ini sesuai dengan yang dilakukan oleh Umar Chusaeni selaku pemasar dan penyelenggara pameran. Umar Chusaeni selalu memberikan pelayanan secara langsung kepada pengunjung atau kolektor yang datang ke Pameran Abstract Party. Segala bentuk informasi mengenai karya baik dari history, harga, bahan dan media karya, hingga karakter seniman disampaikan sendiri oleh Umar Chusaeni. Seluruh rangkaian promosi yang dilakukan oleh penyelenggara pameran dinilai cukup efektif, hal ini dibuktikan dengan jumlah pengunjung pameran meningkat setelah promosi tersebut dilakukan.

\section{Segmentasi, Target Sasaran, Pemosisian (STP)}

Segmentasi

Dalam penelitian ini pemasar merupakan penyelenggara pameran Abstract Party, sedangkan konsumennya adalah publik atau pasar yang disebut pengunjung. Penentuan konsep pameran Abstact Party ini, berdasarkan dari pengamatan tim penyelenggara pameran bahwa pengunjung pameran di galeri Limanjawi lebih tertarik dengan karya abstrak dalam dua tahun terakhir ini. Dari data diatas penyelenggara pameran sudah melakukan pengelempokan pasar sebelum kegiatan ini dilaksanakan, hal ini merupakan salah satu konsep segmentasi apriori. Segmentasi apriori merupakan segmentasi yang dilakukan sebelum produk, jasa, atau ide diluncurkan kepada pasar (Kasali, 1998) Segmentasi pasar pameran Abstract Party ini dapat dikelompokan menjadi beberapa segmen, yaitu berdasarkan variabel geografis, demografis, dan psikografis. Berikut ini beberapa segmen pameran Abstract Party:

a. Geografis

Segmentasi Geografis adalah merupakan segmen yang dikelompokkan berdasarkan negara, wilayah atau kota tertentu. Pameran Abstract Party ini diselenggarakan di kawasan Borobudur, Magelang, maka secara tidak langsung penyelenggara pameran ini menitik beratkan pameran ini diselenggarakan 
untuk masyarakat dan wisatawan di Borobudur dan sekitarnya. Kerjasama Limanjawi dengan masyarakat dan para seniman di Borobudur dan sekitarnya untuk terlibat dalam pameran Abstract Party menunjukan bahwa pameran ini memang ditujukan untuk masyarakat disekitar Borobudur. Rekan kerjasama seperti pemandu wisata, pelaku travel agent, pemandu tamu hotel, dan kerjasama dengan pengelola penginapan atau hotel di area Borobudur. Namun Limanjawi juga mengundang senimanseniman asal kota lain untuk berpartisipasi dalam pameran Abstract Party ini. Tujuan mengundang seniman dari luar kota melainkan untuk memperluas segmen pasar diwilayah tertentu.

b. Demografis

Segmentasi demografis merupakan segmen yang dibedakan berdasarkan usia, jenis kelamin, tingkat pendidikan, pendapatan, agama, pekerjaan dan lain-lain. (Kasali, 1998) Berdasarkan variabel di atas pengunjung pameran Abstract Party dapat dikelompokan sebagai berikut:

1) Usia

Berdasarkan usia pengunjung yang datang ke pameran Abstract Party adalah umum. Segmen usia tidak begitu berpengaruh dalam segmentasi pasar produk pameran Abstract Party. Hal ini karena pameran dapat dinikmati dan diaprseiasi oleh semua kalangan usia, baik itu yang muda ataupun lansia

2) Jenis Kelamin

Sesuai dengan segmen pengunjung pameran Abstract Party, karena Abstract Party dapat dinikmati oleh semua gender baik itu laki-laki maupun perempuan. Segmen pengunjung berdasarkan jenis kelamin juga tidak dapat diterapkan dalam pameran ini, hal ini karena kebutuhan pameran bisa dibutuhkan untuk siapa saja.

3) Tingkat pendapatan.
Segmen pasar berdasarkan pendapatan yaitu kelas menengah kebawah dan menengah ke atas. Segmen ini tergantung kepada tujuan dari masingmasing pengunjung. Kelas menengah kebawah, segmen kelas ini berkaitan dengan tujuan pengunjung yang hanya sekedar ingin melihat kegiatan pameran sebagai hiburan, rata-rata ini adalah masyarakat sekitar. Kelas menengah keatas, segmen kelas ini berkaitan dengan pengunjung yang memiliki tujuan untuk datang ke pameran Abstact Party dan membeli karya dari pameran ini. Pembeli karya dalam pameran ini disebut juga kolektor, yaitu konsumen yang mempengaruhi pasar atau publik seni rupa. (Susanto, 2004) Segmentasi ini berkaitan dengan biaya yang dikeluarkan wisatawan yang meliputi harga karya, tiket, penginapan, serta biaya hidup. Segmen dari tingkat pendapatan dapat dikatakan segmen umum, karena pengunjung memiliki pendapatan dari tingkat bawah hingga atas.

4) Pekerjaan

Konsumen yang memiliki jenis pekerjaan tertentu umunya mengkonsumsi produk-produk tertentu. Pameran Abstract Party merupakan pameran seni rupa, tujuan penyelenggara menyelenggarakan pameran ini ditujukan untuk pengunjung yang sebagian besar merupakan konsumen seni rupa. Konsumen disini dapat disebut publik atau Publik biasanya dikaitkan erat dengan konsumen nonkapital, bisa saja mereka kritikus, kurator, peneliti, pengamat dan dokumentator. Sedangkan pasar berkaitan dengan konsumen yang membeli karya seni dalam pameran yang merupakan salah satu pendorong perubahan wacana dalam pameran, biasa disebut kolektor. 


\section{Psikografis}

Segmen ini dituju untuk para pengunjung yang menginginkan kebutuhan dan memiliki minat khusus. ${ }^{75}$ Kebutuhan dan minat khusus pengunjung dalam pameran Abstract Party berbeda-beda sesuai hal yang disajikan dalam pameran tersebut. Pameran Abstract Party menyajikan pameran seni rupa dengan pertunjukan kesenian dan budaya di daerah Borobudur.

Secara tidak langsung segmen pengunjung dapat dibedakan sesuai dengan kedua kegiatan tersebut. Pertama yaitu pengunjung dengan minat khusus mengenai pameran seni rupa di Borobudur, biasanya pengunjung tertarik dengan wacana pameran, seniman, dan karya seni abstrak yang ditampikan dalam pameran Abstract Party ini. Pengunjung yang memiliki minat khusus terhadap karya kemudian terjadi transaksi disebut konsumen atau kolektor.

Kedua yaitu pengunjung yang memiliki minat khusus dengan pertunjukan kesenian tradisional yang disajikan dalam pembukaan pameran ini. Kedua pengunjung tersebut memiliki minat dan kesukaan dan tujuan dan cara masing-masing untuk menikmati kegiatan, baik yang menikmati kesenian maupun yang bertujuan mengapresiasi wacana, atau membeli karya seni. Dalam hal ini segmentasi pengunjungnya adalah masyarakat, wisatawan, dan pegiat seni di Borobudur dan sekitarnya.

\section{Target Sasaran}

Target pameran Abstract Party adalah masyarakat pendapatan menengah ke bawah dan menengah ke atas. Limanjawi memilih target sasaran pengunjung dalam pameran ini berdasarkan tingkat pendapatan, terdapat dua segmen berdasarkan pendekatan segmen pendapatan. Pertama yaitu publik, dimana publik disini adalah pengunjung pameran yang memiliki sebutan paling netral, dan biasanya disebut non-kapital. Pengunjung disini bisa saja masyarakat atau wisatawan disekitar Borobudur, dan biasanya datang untuk sekedar apresiasi pameran atau karya seni rupa.
Kedua yaitu pasar yang merupakan jenis pengunjung yang lebih spesifik dibanding publik. Pasar adalah pengunjung yang kerap diasumsikan sebagai pemegang urusan kapital atau biasa disebut konsumen atau kolektor. Kolektor merupakan konsumen yang menjadi sosok pendorong perubahan dalam wacana pameran. Sesuai dengan pameran Abstract Party ini yang menyelenggarakan pameran berdasarkan pengamatan mengenai minat pengunjung yang datang ke Limanjawi selama dua tahun terakhir ini. Kolektor atau konsumen yang membeli karya di Limanjawi kebanyakan adalah wisatawan yang sedang berlibur di Borobudur. Rata-rata mereka dipandu oleh pemandu wisata, pelaku travel agent, atau supir penginapan yang mereka tempati untuk datang ke pameran Abstract Party.

Target sasaran yang lebih tajam yaitu pengunjung yang memiliki minat khusus, di mana segmen pengunjung minat khusus ini tergantung dengan jenis kegiatan yang ada dalam pameran itu. Dalam hal ini penyelenggara memfokuskan diri dengan menyajikan beberapa kegiatan, ini agar kegiatan yang disajikan dapat sesuai dengan kebutuhan pengunjung, seperti berikut:

\section{Kesenian dan Budaya}

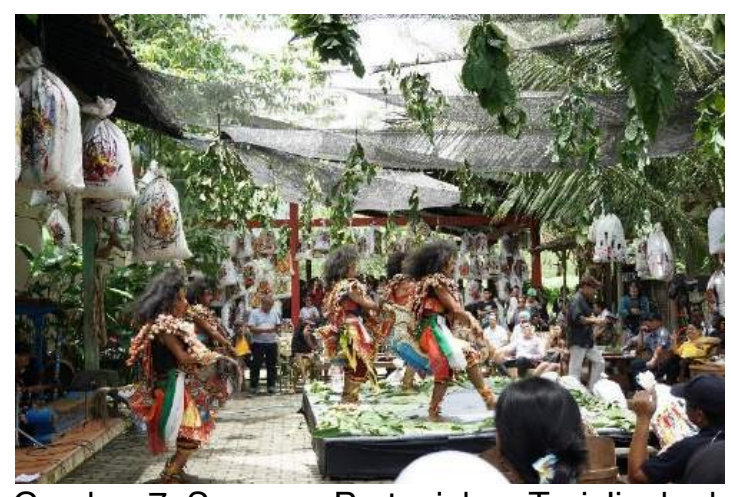

Gambar 7. Suasana Pertunjukan Tari Jingkrak Dalam Pembukaan Pameran Abstract Party. (Sumber: Alfiyati Baroroh, 2018)

Sebagian pengunjung datang ke pameran Abstract Party karena tertarik dengan kesenian dan budaya yang ditampilkan dalam kegiatan pameran Abstract Party ini. Kegiatan ini berupa kesenian tradisional masyarakat 
Borobudur yang ditampilkan dalam pembukaan pameran seperti sejumlah taritarian, dan pertunjukan musik. Pengunjung dapat melihat kesenian tradisional dan budaya asal Borobudur dalam pembukaan pameran. Peminat kegiatan ini merupakan masyarakat sekitar Limanjawi dan wisatawan yang sedang berlibur di Borobudur. Berikut ini adalah suasana pertunjukan kesenian pada saat pembukaan pameran:

\section{Seni Rupa}

Pameran yang ditampilkan dalam kegiatan pameran Abstract Party ini adalah kegiatan pameran seni rupa. Pertama, pengunjung yang tertarik mengenai seni rupa menjadi target pengunjung pameran Abstract Party. Pengunjung-pengunjung tersebut dapat dibedakan menjadi dua, yang pertama yaitu pengunjung non-kapital biasanya adalah seniman, kritikus, pegiat seni rupa, kurator, dan peneliti. (Susanto, Menimbang Ruang Menata Rupa, 2004)

Kedua yaitu target sasaran pengunjung pameran Abstract Party yang memiliki minat khusus mengenai karya seni abstrak. Sebagian pengunjung berminat untuk mengapresiasi karya-karya yang ada dalam pameran tersebut, sebagian lagi biasanya mereka memiliki tujuan khusus untuk mengkoleksi karya seni tersebut. Target sasaran ini bisa disebut pasar, yang diasumsikan sebagai pelaku kapital. Pengunjung ini merupakan pengunjung yang membeli karya dalam pameran untuk dikoleksi, bisa disebut konsumen atau kolektor. Target sasaran ini berminat dengan karya seni Abstrak yang dipamerkan dalam pameran Abstract Party. Kolektor karya seni menjadi salah satu target sasaran karena mereka bukan hanya sekedar mengapresiasi pameran namun juga datang dan mengkoleksi atau membeli karya yang dipamerkan di pameran ini.

\section{Pemosisian}

Pemosisian merupakan proses selanjutnya setelah target sasaran sudah dipilih. Pemosisian pada dasarnya merupakan suatu strategi untuk memasuki otak konsumen.
(Kasali, 1998) Pemosisian merupakan suatu tindakan yang dilakukan pemasar untuk membuat citra produknya dan hal-hal yang ingin ditawarkan kepada pasarnya atau konsumennya dan berhasil memperoleh posisi yang jelas dan mengandung arti dalam benak sasaran konsumennya. Pemosisian penting dalam setiap produk yang dipasarkan, namun akan lebih sulit apabila merek-merek yang bersaing tampak sama, untuk itu untuk memperkuat pemosisian maja diperlukan diferensiasi terhadap produk. Diferensiasi produk merupakan suatu usaha atau strategi untuk menciptakan sesuatu yang dipandang unik dipasar, hal ini untuk membedakan produk kita dengan produk pesaing lain.

Produk dalam penelitian ini adalah pameran Abstract Party Borobudur Today 2018 di Limanjawi Art House. Dengan melihat situasi lokasi pameran yang berada di galeri Limanjawi yang terletak di kawasan wisata Candi Borobudur, pemasar dapat menentukan segmen dan target sasaran, dan pemosisian. Stategi pemasaran dari situasi yang ada dapat diimplementasikan melalui bauran pemasaran yang terdiri dari 4P (product, price, place, dan promotion). Limanjawi mencoba menyuguhkan sesuatu yang sedang menjadi tren dan selera konsumennya yaitu pengunjung pameran. Seperti yang dilakukan dalam pameran Abstract Party ini yang memutuskan konsep dan tema tersebut berdasarkan pengamatan pengelola terhadap ketertarikan pengunjung selama dua tahun terakhir terhadap karya abstrak di Limanjawi.

Untuk mengidentifikasi posisi pasar, pameran Abstract Party ini digelar di galeri Limanjawi yang terletak di kawasan wisata Candi Borobudur. Penyelenggara pameran Abstract Party sebenarnya telah melakukan diferensiasi produk secara tidak langsung. Limanjawi selaku penyelenggara pameran memposisikan dirinya sebagai salah satu galeri seni yang unik dan berbeda dari galeri lain di Borobudur. Galeri-galeri lain seperti Padepokan Apel Watoe, Banyu Bening Art House, Galeri Bumayasta, Elo Progro Art House dan Museum H. Widayat juga menampilkan 
karya-karya seni rupa untuk dipamerkan. Dalam pengemasan pameran mereka hampir sama dengan Limanjawi yaitu menyuguhkan karya seniman lokal atau internasional, namun mereka jarang menyuguhkan kesenian tradisional dalam pembukaan pameran.

Upaya Limanjawi menampilkan kombinasi seni pertunjukan dan seni rupa dalam pembukaan menjadikan galeri Limanjawi dan pameran Absract Party ini berbeda dengan pameran di galeri lain. Dengan begitu pameran Abstact Party memiliki posisi tersendiri dalam benak pengunjung, yaitu karena menyajikan pameran secara unik dan berbeda, baik dari pengemasan dan juga konsep pameran sendiri. Galeri lain merupakan pesaing galeri Limanjawi Art House, salah satunya yaitu Padepokan Apel Watoe. Jika dibandingkan berdasarkan jumlah pameran yang digelar di Limanjawi satu tahun bisa mencapai 6 kali, lebih banyak jika dibandingkan jumlah pameran di Padepokan Apel Watoe yang hanya sekitar 3 sampai 4 kali dalam satu tahun. Limanjawi Art House berada di posisi galeri yang paling aktif di Borobudur, karena Limanjawi dapat menyajikan kegiatan pameran dengan jumlah lebih banyak dibanding pameran di galeri lain.

\section{Kesimpulan}

Strategi pemasaran yang sudah diterapkan oleh Limanjawi Art House di pameran Abstract Party dengan bauran pemasaran meliputi produk, harga, tempat, dan promosi. Pameran sudah dikembangkan secara efektif seperti Abstract Party terbagi menjadi beberapa produk, seperti produk inti, produk nyata dan produk tambahan. Promosi yang dilakukan dengan berbagai media dan berdampak dengan jumlah pengunjung yang datang sebanyak 383 pengunjung.

Strategi pemasaran yang diterapkan oleh Limanjawi dalam pameran Abstract Party mengacu pada konsep segmentasi, target sasaran, dan pemosisian. Segmen geografis berdasarkan lokasi pameran yang berada di Borobudur, hal ini menunjukan segmen pengunjung adalah masyarakat dan wisatawan yang berada di Borobudur. Segmen demografis berdasarkan tingkat pendapatan, dan pekerjaan. Sedangkan segmen psikografis adalah pengunjung dengan minat khusus terhadap seni rupa dan kesenian dan kebudayaan di Borobudur.

Target sasaran, Limanjawi dalam Pameran Abstract Party ini memilih secara khusus segmen mana yang akan dibidik berdasarkan segmen demografis dan psikografis. Segmen demografis yaitu daerah Borobudur sedangkan segmen psikografis berdasarkan minat khusus pengunjung terhadap seni rupa dan kesenian dan kebudayaan di Borobudur.

Pada tahap pemosisian pameran Abstract Party Borobudur Today 2018 di Galeri Limanjawi Art House mampu memposisikan diri sebagai pameran yang unik dan dan berbeda dari pameran di galeri lain dari segi pengemasan pemeran maupun konsep.

\section{Daftar Pustaka}

Borobudur, B. K. (2016). Selayang Pandang. Magelang: Balai Konservasi Borobudur.

Borobudur, K. (2018). Data Daya Tarik Wisata Kecamatan Borobudur 2017. Borobudur, Magelang.

Borobudur, K. K. (2018). Data Hotel dan Homestay Kecamatan Borobudur 2017. Magelang: Kantor Kecamatan Borobudur.

Buku Tamu Pameran Abstract Party Borobudur Today 2018 . (2018). Magelang: Limanjawi Art House.

Chusaeni, U. (2018). Galeri Limanjawi Art House. Borobudur, Magelang.

Dian, E. (2016). Kearsitekturan Candi Borobudur. Magelang: Balai Konservasi Borobudur.

House, L. A. (2018). Katalog Pameran Abstract Party Borobudur Today 2018 . Magelang: Limanjawi Art House. 
Kasali, R. (1998). Membidik Pasar Indonesia Segmentasi Targenting Positioning. Jakarta: PT Gramedia Pustaka Utama.

Keller, P. K. (2009). Manajemen Pemasaran Edisi Ketiga Belas (Jakarta: Jakarta: Penerbit Erlangga.

Kotler, P. (2000). Marketing Management. United States of America: Prentice-Hall.

Mardalis. (2004). Metode Penelitian Suatu Pendekatan Proposal. Jakarta: PT. Bumi Aksara.

Nazir, M. (2014). Metode Penelitian. Bogor: Penerbit Ghalia Indonesia.

Pameran, B. T. (2018). Abstract Party Borobudur Today 2018. Magelang.

Paw, D. ( 2018). Padepokan Apel Watoe. Borobudur, Magelang.

Philip Kotler, K. L. (2009). Manajemen Pemasaran Edisi Ketiga Belas. Jakarta: Penerbit Erlangga.

Rosidi, R. (2017). Katalog Pameran Borobudur Today. Magelang: Limanjawi Art House.
Sunyoto, D. (t.thn.). Teori, Kuesioner, \& Analisis Data Untuk Pemasaran Dan Perilaku Konsumen. Yogyakarta: Graha Ilmu.

Sunyoto, D. ( 2015). Strategi Pemasaran. Yogyakarta: CAPS (Center for Academic Publishing Service).

Suryabrata, S. (2012). Metode Penelitian. Jakarta: PT RajaGrafindo Persada, .

Susanto, M. (2004). Menimbang Ruang Menata Rupa. Yogyakarta: Galang Press.

Wahyuningsih. (2016). Meninjau Kembali Tujuan Pendirian dan Fungsi Museum di Kompleks Taman Wisata Candi Borobudur. Jurnal Konservasi Cagar Budaya Borobudur, 49.

Wahyuningsih. (Vol 10 No. 2 Desember 2016). Meninjau Kembali Tujuan Pendirian dan Fungsi Museum di Kompleks Taman Wisata Candi Borobudur. Jurnal Konservasi Cagar Budaya Borobudur, 49. 